Part 6

General Electrochemistry 



\section{Using Scanning Electrochemical Microscopy (SECM) for measuring electrochemical current change in fibroblast cell culture treated}

\author{
J. M. Zanluchi ${ }^{1}$ \\ C. Dal Pizzol \\ R. M. Stuart ${ }^{1}$ \\ M. C. Baptista'
}

P. R. D. Marangoni²

M. A. C. Berton ${ }^{2}$

L. C. Ferracin ${ }^{2}$

G. C. Dieamant ${ }^{1}$

\section{Abstract}

Scanning electrochemical microscopy (SECM) is a technique of interest to obtain information about chemical, electrochemical, kinetics and topographical activities of materials. Even though this technique is applied to non-biological systems, as in studies of metal corrosion, recently it has been enhanced, being widely used in research labs using cell culture. In general, this technique analyzes and tracks the electric current using ultra/microelectrodes placed near the surface of a sample submerged in electrolyte solution. The action of electrical signals has extensive relationship with the human body, its physiological effects are based on the consequent improvement of nutrition, oxygenation and cells metabolism as a whole, and these signals also stimulate fibroblasts to produce more and better collagen. Therefore, this study was based on in vitro monitoring of electrochemical current in fibroblasts cell culture before and after use of cosmetic formulations containing ingredients for anti-aging treatment. Electrochemical current was evaluated in cell culture of fibroblasts by scanning cells surface and using chronoamperometry technique to measure the electrochemical current, using three different cosmetic formulations treatment: tonic, gel cream and serum, applied separately and also in combined use, in order to verify the change of bioelectricity.

Keywords: Scanning electrochemical microscopy, electrochemical current, and bioelectricity.

1 Grupo Boticário, Research \& Development. São José dos Pinhais, Paraná, Brazil.

2 SENAI Institute of Innovation in Electrochemistry, Curitiba, Paraná, Brazil. 


\section{Introduction}

Knowledge of bioelectric current is essential in order to understand fundamental processes of cellular life. These signals are capable to control cell activity or establish communication operating in various physiological processes, also acting on the skin. Effects of these signals are based on the consequent improvement of cells and tissues nutrition, oxygenation and metabolism, another effect is stimulus of fibroblasts to produce more and better collagen.

Different techniques are used to measure bioelectric signals and recently the electrochemical microscopy has been used in research laboratories mainly for analysis in cell culture. This technique consists in monitoring the electrochemical potential or current using a microelectrode positioned close to the surface of a solid substrate (like metals) or biological membranes, both immersed in a solution. The operating principle of the microelectrode involves the shift in $\mathrm{x}, \mathrm{y}$ (scanning of the surface) and z-axys (approach) at constant speed.

In vitro studies related to electrical signals on the skin are intesnded to elucidate the cellular communication regarding cells ability to store and/or maintain a potential of action along the plasma membrane. Malfunction in bioelectric current transport can cause loss of important functions involved in cellular aging mechanism.

Therefore, the purpose of the present study is to evaluate electrochemical current variation, using SECM, in a cell culture system treated with cosmetic formulations containing treatment ingredients.

\section{Materials and methods}

experiment was conducted using Human neonatal Dermal Fibroblast (HDF) from Cascade Biologics. The glass slide was supplemented with fetal bovine serum (GIBCO) for 24 hours at $37^{\circ} \mathrm{C}$ under $\mathrm{CO} 2$. Then the slides were treated with three formulations containing cosmetic ingredients separately and in a combined use for the achievement of measured current through SECM.

In order to determine the applied reduction potential, a cyclic voltammetry was realized using buffer PBS (Phosphate buffered saline), mediator Hexaammineruthenium III Chloride [Ru (NH3) 6CL], for working electrode was used a platinum microelectro with $10 \mu \mathrm{m}$ of diameter, a platinum coil as a counter electrode and a reference electrode of $\mathrm{Ag} / \mathrm{AgCl}$. A linear z-scan was also performed, using approach curve and scanning $\mathrm{X} / \mathrm{Y}$ with the polarized electrode $-250 \mathrm{mV}$ and $\mathrm{Ag} / \mathrm{AgCl}$ as reference electrode. A chronoamperometry was also performed to measure the electrochemical. 


\section{Results and discussion}

Microelectrodes distance on cultured HDF cells was optimized for $9 \mu \mathrm{m}$ and electrochemical current on the top of the cells were between -0.257 and -0.327 $\mathrm{nA}$. These values were used as controls for subsequent evaluations and also as a control experiment to confirm no changes in microelectrode measurements and cells adhesion to glass slide during all the experiment.

The cosmetic formulations containing treatment ingredient were named " $T$ ” for tonic , "S “ for the serum, " G” for the gel , "TSG " for combined usage of all three formulations, and "TS " for combination of tonic and serum. Table 1 shows electrochemical current variations in cell culture (HDF) before addition of formulations, after separated addition of each formulation and in a combined formulation.

Table 1 Variation of electrochemical current on cell culture, before and after the addition of cosmetic formulations containing treatment ingredients.

\begin{tabular}{|l|c|c|c|c|c|}
\hline \multicolumn{1}{|c|}{ Parameters } & \multicolumn{1}{|c|}{ T } & S & G & TSG & TS \\
\cline { 2 - 6 } & $\begin{array}{c}\text { Cell } \\
\text { Culture }\end{array}$ & $\begin{array}{c}\text { Cell } \\
\text { Culture }\end{array}$ & $\begin{array}{c}\text { Cell } \\
\text { Culture }\end{array}$ & $\begin{array}{c}\text { Cell } \\
\text { Culture }\end{array}$ & $\begin{array}{c}\text { Cell } \\
\text { Culture }\end{array}$ \\
\hline $\begin{array}{l}\text { Electrochemical current } \\
\text { on cell culture (HDF) } \\
\text { before treatment (nA). }\end{array}$ & $-0,281$ & $-0,309$ & $-0,281$ & $-0,315$ & $-0,301$ \\
\hline $\begin{array}{l}\text { Electrochemical current } \\
\text { on cell culture (HDF) } \\
\text { after treatment (nA). }\end{array}$ & $-0,563$ & $-0,441$ & $-0,567$ & $-0,519$ & $-0,523$ \\
\hline $\begin{array}{l}\text { Electrochemical Current } \\
\text { Variation (\%). }\end{array}$ & $100 \%$ & $42 \%$ & $101 \%$ & $65 \%$ & $74 \%$ \\
\hline
\end{tabular}

The greatest variations in electrochemical current under cell culture occurred with the addition of tonic $(\mathrm{T})$ and gel $(\mathrm{G})$ having approximately $100 \%$ during 20 minutes exposure. Addition of serum $(S)$ showed the lowest current variation $(42 \%)$, but with the combined addition of tonic $(\mathrm{T})$ together with gel $(\mathrm{G})$ or tonic (T) together with serum, an increase in current was detected, respectively to 65 $\%$ and $74 \%$.

Initial values were maintained, even after addition of treatment formulation. This was verified by cyclic voltammetry, keeping the same optimized distance of $9 \mu \mathrm{m}$ between microelectrode and cell culture, reaching the same position of electrode while was into electrolytic solution before treatments. (Figure 1). 


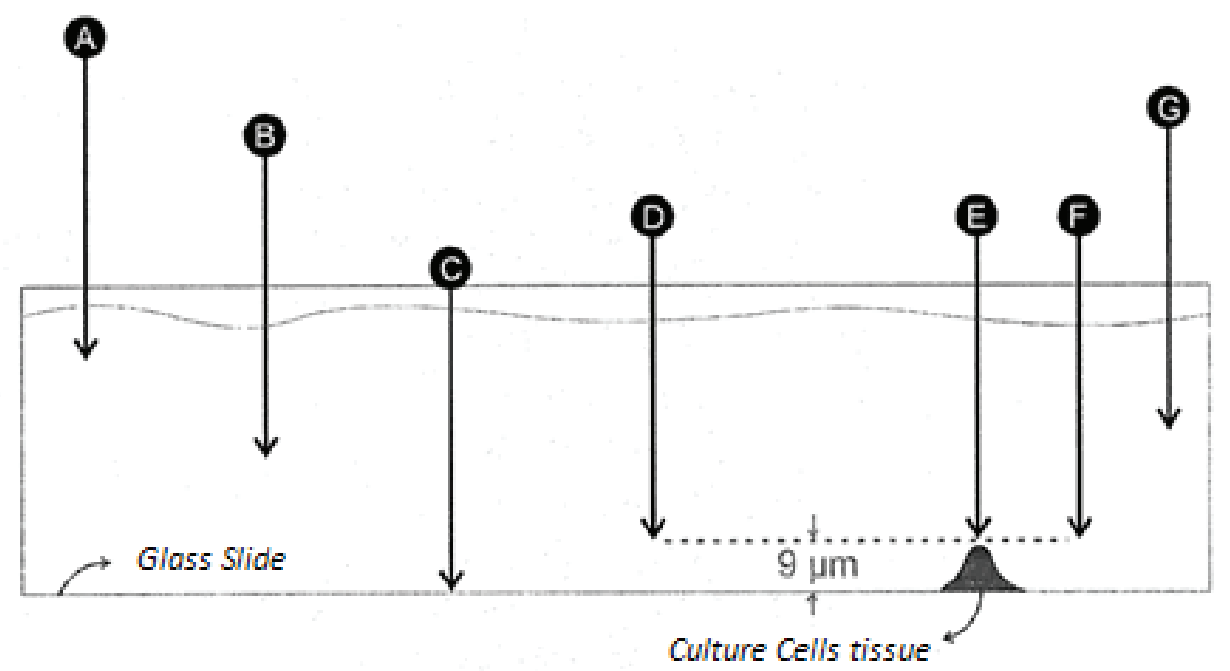

Figure 1 Illustration of microelectrode placement in the analysis by SECM before and after addition of treatment formulations.

Note: A: Microelectrode position near of solution surface (electrolyte solution = PBS + mediator); B: Microelectrode in the bulk of solution; C: Contact position with glass slide; D: Optimized position of $9 \mu \mathrm{m}$ on culture cells tissue; E: Evaluation position (before and after treatment) of electrochemical current of the top cell; F: Checking position after treatment by chronoamperometry; G: Checking position after treatment through cyclic voltammetry.

\section{Conclusion}

Reported amount of electrochemical current in cell culture of fibroblasts after exposure to cosmetic formulations containing treatment ingredients showed bioelectrical change in cells, and that this is essential for processes cellular life. The separate addition or in combination of three different formulations, tonic $(\mathrm{T})$, gel $(\mathrm{G})$ and serum $(\mathrm{S})$, increased electrochemical current in the cells, enabling a better understanding of main functions maintenance in cells. Furthermore, the use of Scanning electrochemical microscopy (SECM) technique has proved to be effective in monitoring electrochemical current in biological systems.

\section{References}

JEONG, Y. Introduction to Bioelectricity. Department of Bio and Brain Engineering, Korea Advanced Institute of Science and Technology. Republic of Korea, 2011. 
LIMA, A.S.; Uso da microscopia eletroquímica no estudo da dinâmica de processos eletródicos em superfícies funcionalizadas. Dissertação- (mestrado em Química) - Instituto de Química da Universidade de São Paulo - IQ/USP. São Paulo, 2011.

LOOF. A.; HAES.W.; BOERJAN. B.; SCHOOFS. L.; The Fading in Electricity Theory of Ageing: The missing biophysical principle? Ageing Research Reviews. Journal homepage. Department of Biology, KU Leuven - University of Leuven, Belgium, 2012.

MARANGONI, P.F.D.; BERTON, M.A.C.; FERRACIN, L.C.; Relatório de dados técnicos de Bioletricidade: Fase 2. Instituto SENAI de Inovação em eletroquímica. SENAI - Campus da Indústria. Curitiba Paraná, Brasil, 2015.

NUCCITELLI, R.; NUCCITELLI, P.; LI, C.; NARSING, S.; PARISER, D.M.; LUI, KAYING. The electric field near human skin wounds declines with age and provides a non-invasive indicator of wound healing. Wound Repair Regeneration. United States, Vol. 19, p. 645-655, 2011.

NUCCITELLI, R.; LUI, K.; TRAN, K.; ATHOS, B.; KREIS, M.; NUCCITELLI, P. Measuring the electric field in skin to detect malignant lesions. Biosensors and Molecular Technologies for Cancer Diagnostics. Editors, Keith E. Herold; Avraham Rasooly. p.765, (series in sensors), United States, 2012.

OLIVEIRA. V.C.; A Eletroestimulação por Micros correntes na Revitalização Facial. Trabalho de Conclusão de Curso de Especialização Lato Sensu em Estética. Faculdade Redentor. Instituto Itesa. São Paulo, 2011.

TROLLINGER, D. R.; ISSEROFF, R. R.; NUCCITELLI, R.; Calcium Channel Blockers Inhibit Galvanotaxis in Humans Keratinocytes. Journal of Cellular Physiology. Department of Dermatology, University of California, Davis, California, 2002. 
